\title{
PENGARUH HASIL PERKEBUNAN KEMIRI TERHADAP KEHIDUPAN SOSIAL EKONOMI MASYARAKAT DESA BENTENG TADO KECAMATAN LEMBOR SELATAN KABUPATEN MANGGARAI BARAT NUSA TENGGARA TIMUR
}

\author{
${ }^{1)}$ Kamilus Adi Chandra; ${ }^{2)}$ Mustika Arif Jayanti. \\ 1,) 2) Universitas Kanjuruhan Malang \\ Email: ${ }^{1)}$ chandrakamilus@ gmail.com; ${ }^{2)}$ ratumustika25@gmail.com
}

\begin{abstract}
Abstrak
Masyarakat Desa Benteng Tado pada umumnya memiliki banyak perkebunan kemiri. Kemiri merupakan tanaman pohon asli indo-malaysia yang bijinya di manfaatkan sebagai sumber minyak dan rempah-rempah dan sangat berguna bagi masyarakat dunia. Tujuan dari penelitian ini adalah untuk mengetahui apa pengaruh hasil perkebunan kemiri terhadap kehidupan sosial ekonomi masyarakat Desa Benteng Tado Kecamatan Lembor Selatan Kabupaten Manggarai Barat Propinsi Nusa Tenggara Timur.Metode yang digunakan dalam penelitian ini yaitu metode korelasional. Data hasil penelitian dianalisis secara statistik dengan teknik analisis data menggunakan pengukuran koefisien pearson produck moment dengan menggunakan program bantu SPSS 20 for windows. Berdasarkan hasil uji statistik pearson product moment correlations, diketahui nilai koefisien korelasi antara hasil perkebunan kemiri dengan kehidupan sosial ekonomi sebesar $=0,937$ dengan signifikansi $=0,000$. Nilai sig. $=0,000<0,05$, sehingga hipotesis yang diajukan diterima. Hal ini menunjukan bahwa ada pengaruh antara hasil perkebunan kemiri dengan kehiduan sosial ekonomi masyarakat Desa Benteng Tado Kecamatan Lembor Selatan Kabupaten Manggarai Barat Nusa Tenggara Timur..
\end{abstract}

Kata Kunci: Perkebunan kemiri, kehidupan sosial ekonomi.

\section{PENDAHULUAN}

Desa Benteng Tado merupakan salah satu desa yang terletak di kecamatan lembor selatan kabupaten Manggarai Barat provinsi Nusa Tenggara Timur.Masyarakat Desa Benteng Tado Sebagian besar memiliki perkebunan kemiri yang notabene tanaman perkebunan tahunan. Perkebunan kemiri bagi masyarakatDesa Benteng Tado adalah komoditi yang menjadi urat nadi untuk menunjang kehidupan sosial ekonomi. Akibat keberadaan perkebunan kemiri tentu berpengaruh pada kehidupan sosial ekonomi masyarakat.Pengaruh yang timbul pada masyarakat yang memiliki perkebunan kemiri tentu sangat berbeda,ada yang pengaruh ke arah positif dan ada pula yang ke negatif.Hal ini tergantung pada luas lahan, pengolahan, jumlah tanamanya dan umur tanaman serta biaya tenaga kerja yang berbeda-beda diantara masyarakat yang memiliki perkebunan kemiri.

Tanaman kemiri yang notabene tanaman perkebunan tahunan banyak diusahakan oleh masyarakat Desa Benteng Tado. Rosman (2005) menjelaskan "kemiri adalah salah satu tanaman industri dari family Euphorbiaceae yang tersebar di daerah tropik dan subtropik". Keberadaan perkebunan kemiri rakyat ini tidak hanya sebagai penghasil devisa tetapi berperan dalam menyediakan lapangan pekerjaan bagi masyarakat yang ada di sekitarnya.Sehingga akibat keberadaan perkebunan kemiri rakyat tersebut dapat mempengaruhi dan 
mengubah kehidupan sosial ekonomi masyarakat Desa Benteng Tado.

Kehidupan sosial ekonomi dilingkungan masyarakat berbeda-beda. Astrawan (2014) menjelaskan kehidupan sosial ekonomi adalah "kedudukan atau posisi seseorang dalam kelompok masyarakat yang ditentukan oleh aktivitas ekonomi". Keberadaan perkebunan kemiri rakyat tidak hanya memberikan kesempatan kerja tetapi memberikan suatu harapan untuk terciptanya perubahan kehidupan sosial ekonomi masyarakat ke arah yang positif.Perubahan yang terjadi akibat perkebunan kemiri diharapkan perubahan ke arah yang lebih baik, dalam arti mereka dapat memperbaiki tatanan kehidupan sosial ekonomi.

Kehidupan sosial ekonomi masyarakat yang memiliki perkebunan kemiri di Desa Benteng Tado masih sangat rendah dan tidak berbeda jauh dengan masyarakat yang tidak memiliki perkebunan kemiri.Hal ini diketahui dari kondisi pendidikan anaknya, kondisi tempat tinggal dan fasilitas yang dimilikinya.Kondisi pendidikan anak yang memiliki perkebunan kemiri masih sangat rendah dimana masih ada anaknya yang tamatan SD. Begitupun kondisi tempat tinggal mereka yang masih sederhana dimana masih banyak rumah yang beralaskan tanah.Dari kondisi pendidikan dan kondisi tempat tinggal tersebut kita bisa mengetahui sedikit kehidupan sosial ekonomi masyarakat.

Perkebunan kemiri rakyat di Desa Benteng Tado memperkerjakan buruh perkebunan.Buruh perkebunan kemiri rakyat ini sebagaian besar merupakan masyarakat Desa Benteng Tado itu sendiri.Dalam hal ini masyarakat Desa Benteng Tado adalah mereka yang hidup dan tinggal menetap di Desa Benteng Tado.Dengan bekerja sebagai buruh perkebunan kemiri, mereka berharap adanya perubahan sosial ekonomi dan menjadi buruh perkebunan kemiri sebagai bentuk usaha untuk meningkatkan ekonominya selain dari hasil perkebunan kemiri yang dimiliki.

Hasil perkebunan kemiri yang dimiliki masyarakat tentu berbeda-beda. Sihombing (2011) menjelaskan "hasil perkebunan kemiri dipengaruhi oleh empat faktor yang dianggap paling berperan dalam menentukan besar kecilnya hasil produksi yang diperoleh setiap periode waktu, yaitu luas lahan, umur tanaman, jumlah tanaman yang menghasilkan serta tenaga kerja". Perkebunan kemiri rakyat yang dimiliki masyarakat Desa Benteng Tado tentu luas lahan, umur tanaman, jumlah tanaman yang menghasilkan serta biaya tenaga kerjanya berbeda-beda.Hal ini tentu berpengaruh pada hasil perkebunan kemiri masyarakat Desa benteng Tado.

Hasil perkebunan kemiri yang sudah ditanami tentu diambil dari bijinya yang notabene prosesnya sangatlah panjang.Memproses kemiri menjadi komoditi yang layak dijual kepada para pedagang membutuhkan biaya yang cukup besar untuk menyewa buruh perkebunan.Buruh perkebunan tersebut nantinya mengumpulkan kemiri yang sudah jatuh dari pohonya kemudian mengeluarkan bijinya dan selanjutnya dijemur hingga kering.Setelah biji kemiri yang dijemur telah kering selanjutnya kemiri tersebut dipecahkan untuk memisahkan cangkang dengan butirnya dengan alat yang serba sederhana dan tradisional.Butir kemiri ini selanjutnya di jual kepada para pengusaha yang menjual kemiri ke pasar nasional maupun internasional.

Berdasarkan latar belakang diatas maka rumusan masalah dalam penelitian ini 
adalah Bagaimana Pengaruh Hasil Perkebunan Kemiri Terhadap Kehidupan Sosial Ekonomi Masyarakat Desa Benteng Tado Kecamatan Lembor Selatan Kabupaten Manggarai Barat Nusa Tenggara Timur?.

\section{METODE PENELITIAN}

Adapun rancangan dalam penelitian ini adalah sebagai berikut.

\begin{tabular}{|l|l|}
\hline $\begin{array}{l}\text { Hasil } \\
\text { kerkebunan }\end{array}$ & $\begin{array}{c}\text { Kehidupan } \\
\text { sosial } \\
\text { ekonomi }\end{array}$ \\
\hline
\end{tabular}

Gambar 1.Pengaruh Variabel $X$ terhadap Variabel Y.

1. Defenisi Operasional

a. Perkebunan adalah kegiatan yang mengusahakan tanaman tertentu pada tanah.

b. Kemiri merupakan tanaman perkebunan tahunan yang memilki banyak manfaat dan tersebar didaerah tropis.

c. Kehidupan sosial ekonomi merupakan kehidupan sosial ekonomi masyarakat yang dilihat dari tingkat pendapatan, tingkat pendidikan, pekerjaan, dan fasilitas yang dimilikinya.

2. Teknik Pengumpulan Data

a. Angket

Angket digunakan untuk mendapatkan data hasil perkebunan kemiri dan kehidupan sosial ekonomi masyarakat Desa Benteng Tado yang memiliki Perkebunan kemiri. Teknik pengumpulan data dilakukan dengan cara memberikan pertanyaan tertulis kepada responden untuk dijawab. Jenis kuesioner yang digunakan dalam penelitian ini adalah kuesioner tertutup. Responden cukup memilih jawaban yag disediakan.

\section{b. Observasi}

Observasi yang digunakan dalam penelitian ini mengunakan observasi secara langsung. Observasi ini dilakukan di Desa Benteng Tado Kecamatan Lembor Selatan Kabupaten Manggarai Barat Nusa Tenggara Timur. Hal yang diobservasi disini adalah kondisi perkebunan kemiri dan aktivitas pengelolaannya.

\section{Teknik Analisis Data}

Teknik analisis data yang digunakan dalam penelitian ini adalah

a. Uji Normalitas

Uji normalitas dilakukan untuk memeriksa apakah nilai variabel bebas $X$ didistribusikan secara normal terhadap nilai variabel Y. Dalam penelitian akan diperiksa hubungan antara faktor $\mathrm{Y}$ (sebagai varabel terikat) dengaan indikator terkait $\mathrm{X}$ (sebagai variabel bebas) dengan faktor yang dimaksud.Dalam penelitian ini uji normalitas dilakukan dengan mengamatipenyebaran data pada sumbu diagonal suatu grafik.

b. Pengukuran koefisien pearson product moment

Mengacu pada jenis penelitian ini adalah penelitian yang bersifat verifikatif, yaitu penelitian yang memerlukan hipotesa yang harus dibuktikan kebenarannya. Untuk menganalisa data dari hasil penelitian ini, penulis menggunakan pengukuran koefisien pearson product moment, dimana rumusnya adalah sebagai berikut :

$$
\mathrm{r}_{\mathrm{xy}}=\frac{\sum X Y}{\sqrt{\left(\Gamma \cdot X^{2}\right)\left(\Gamma \cdot Y^{2}\right)}}
$$

Keterangan

rxy $=$ Koefisien korelasi antara $\mathrm{x}$ dan $\mathrm{y}$

$\mathrm{xy}=$ Jumlah product dari $\mathrm{x}$ dan $\mathrm{y}$

$\mathrm{x}=$ Hasil Perkebunan kemiri

$\mathrm{y}=$ Kehidupan sosial ekonomi 
Selanjutnya untuk mengukur interprestasi dari korelasi tersebut atau dengan kata lain untuk mengadakan test signifikansi korelasi, maka penyusun menggunakan taraf signifikan 5\% atau dasar taraf kepercayaan $95 \%$ yang berarti bahwa penyusun mengambil resiko salah dalam mengambil keputusan sebanyak-banyaknya $5 \%$ atau benar dalam keputusannya sedikitnya $95 \%$ dengan ketentuan yaitu jika harga rxy hitung lebih besar (>) dari harga kritik $r$ product moment, maka menunjukkan adanya signifikansi atau terdapat korelasi (hubungan) antara kedua variabel. Jika harga rxy hitung lebih kecil $(<)$ dari harga kritik $\mathrm{r}$ product moment, maka menunjukkan tidak ada korelasi antara kedua variabel, yaitu antara hasil perkebunan kemiri dan kehidupan sosial ekonomi.

c. Regresi Linear Sederhana

Analisis regresi merupakan analisis hubungan yang melibatkan variabel bebas (independen) dengan variabel terikat (dependen). Dari Hubungan tersebut akan dicari bentuk hubungannya dengan tujuan prediksi mengenai nilai variabel terikat berdasarkan nilai variabel bebas yang diketahui atau ditentukan. Biasanya teknik regresi disertakan dengan teknik korelasi, karena sama-sama menghubungkan dua variabel. Analisis regresi dalam penelitian ini menggunakan analisis regresi sederhana. Dengan persamaan koefisien regresi sebagai berikut:

$$
\begin{aligned}
& \mathrm{K}=\mathrm{a}+\mathrm{bx} \\
& \mathrm{a}=\text { Intercept (Konstanta) } \\
& \mathrm{b}=\text { Koefisien regresi } \\
& \mathrm{X}=\text { Variabel Bebas (independen) } \\
& \mathrm{Y}=\text { Variabel Terikat (dependen) }
\end{aligned}
$$

\section{HASIL DAN PEMBAHASAN}

Hasil analisis deskriptif

Tabel 1. Tabel Hasil Analisis Deskriptif

\begin{tabular}{lccc}
\hline & $\begin{array}{c}\text { Hasil } \\
\text { perkebunan } \\
\text { kemiri }\end{array}$ & $\begin{array}{c}\text { Kehidupan } \\
\text { sosial } \\
\text { ekonomi }\end{array}$ & $\begin{array}{c}\text { Valid N } \\
\text { (listwise) }\end{array}$ \\
\hline $\mathrm{N}$ & 54 & 54 & 54 \\
Range & 11 & 8 & \\
Minimum & 21 & 24 & \\
Maximum & 32 & 32 & \\
Sum & 1450 & 1540 & \\
Mean & 26,85 & 28,52 & \\
Std. & 2,891 & 2,640 & \\
Deviation & & & \\
Variance & 8,355 & 6,971 & \\
\hline Sumber: data yang &
\end{tabular}

Sumber: data yang diolah 2017

Dari tabel di atas dapat dilihat bahwa variabel hasil perkebunan kemiri dengan jumlah data $(\mathrm{N})$ sebanyak 54 mempunyai rata-rata (mean) 26,85 dengan nilai minimum 21 , maksimaum 32 , range 11 , sum 1450 , variancenya 8,355 sedangkan standar deviasinya sebesar 2,891. Variabel kehidupan sosial ekonominya dengan jumlah data $(\mathrm{N})$ sebanyak 54 mempunyai rata-rata (mean) 28,52 dengan nilai minimum 24, maksimaum 32 , range 8 , sum 1540 , variance 6,971 sedangkan standar deviasinya sebesar 2,640 .

Hasil Uji Hipotesis Hasil Perkebunan Kemiri Dan Kehidupan Sosial Ekonomi

1. Uji Normalitas

Uji normalitas bertujuan untuk mengetahui apakah data yang dianalisis terdistribusi normal atau tidak. Perhitungan uji normalitas dilakukan denga menggunakan bantuan SPSS 20 for Windows dengan analisis grafik dengan cara melihat normal P-P Plot of Regression Standartdized resudal.Hasil dari uji normalitas dengan grafik P.Plot dapat dilihat pada grafik 1dibawah ini: 


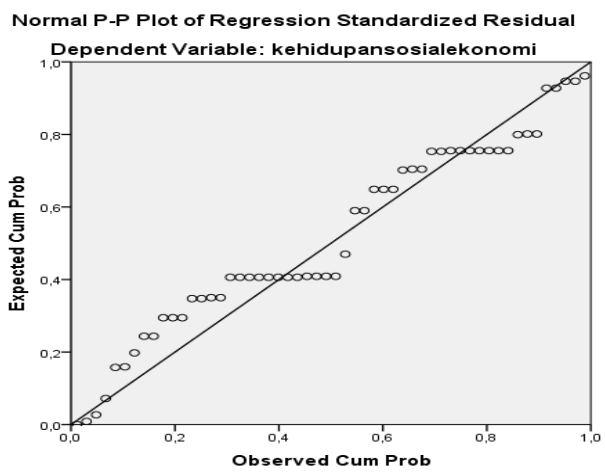

Gambar 2. grafik normal P-Plot ofRegression Standardized Resudual

Berdasarkan gambar 4.5 dapat diketahui bahwa data menyebar disekitar garis diagonal dan mengikuti arahdiagonal sehingga dapat disimpulkan bahwa data tersebut terdistribusi normal.

2. Uji Korelasi Pearson Product Moment

Uji korelasi digunakan untuk mengetahui seberapa besar hubungan antara variabel bebas hasil perkebunan kemiri (X) dengan variabel terikat kehidupan sosial ekonomi (Y). Uji korelasi ini dilakukan dengan bantuan SPSS 20 For Windows dengan melihat taraf signifikan $5 \%$ dan nilai pearson correlation rtabel sebesar 0,226. Hasil uji korelasi dapat dilihat pada tabel berikut:

Tabel 2. Hasil Uji Korelasi Product Moment

\begin{tabular}{lll}
\hline & $\begin{array}{l}\text { Hasil } \\
\text { Perkebunan } \\
\text { Kemiri }\end{array}$ & $\begin{array}{l}\text { Kehidupan } \\
\text { Sosial } \\
\text { Ekonomi }\end{array}$ \\
\hline Pearson & 1 &, $937^{* *}$ \\
Correlation & &, 000 \\
Sig. (2-tailed) & & 54 \\
N & 54 & 1 \\
Pearson &, $937^{* *}$ & \\
Correlation &, 000 & 54 \\
Sig. (2-tailed) &, 54 & N
\end{tabular}

Sumber: data yang diolah 2017

Berdasarkan hasil analisis data yang diperoleh dari korelasi produk moment adalah positif 0,937 besaran angka korelasi menunjukan bahwa korelasi antara hasil perkebunan kemiri dengan kehidupan sosial ekonomi berada dalam kategori kuat. Perolehan Sig. $=0,000<0,005$ yang menunjukan bahwa ada pengaruh antara hasil perkebunan kemiri dengan kehidupan sosial ekonomi adalah signifikan.

Nilai Signifikan antara hasil perkebunan kemiri dengan kehidupan sosial ekonomi sebesar 0,000 dimana sig. $<0,005$ dan nilai pearson correlatioon sebesar 0,937 dimana $r_{\text {hitung }}>r_{\text {tabel }}(0,226)$. Dengan demikian dapat disimpulkan bahwa hasil perkebunan kemiri berkorelasi dengan kehidupan sosial ekonomi.

Tujuan analisis data ini untuk mengetahui ada tidaknya pengaruh dari hasil perkebunan kemiri (X) terhadap kehidupan sosial ekonomi (Y). Hipotesis yang digunakan adalah sebagai berikut:

$\mathrm{H}_{0}=$ Tidak ada pengaruh antara hasil perkebunan kemiri terhadap kehidupan sosial ekonomi masyarakat Desa Benteng Tado Kecamatan Lembor Selatan Kabupaten Manggarai Barat.

$\mathrm{H}_{\mathrm{a}}=$ Ada pengaruh antara hasil perkebunan kemiri terhadap kehidupan sosial ekonomi masyarakat Desa Benteng Tado Kecamatan Lembor Selatan Kabupaten Manggarai Barat.

Berdasarkan hasil analisis data karena sig. $=0,000<0,05$ maka $\mathrm{H}_{0}$ ditolak $\mathrm{H}_{\mathrm{a}}$ diterima.

\section{Uji Regresi Linear Sederhana}

Untuk menganalisis hubungan antara variabel bebas hasil perkebunan kemiri (X) terhadap kehidupan sosial ekonomi (Y), peneliti menggunakan rumus regresi linear sederhana. Hasil dari analisis regresi linear sederhana dapat dilihat pada tabel berikut: 
Tabel 3. Hasil uji Regresi Linear Sederhana

\begin{tabular}{|c|c|c|c|c|}
\hline \multirow[t]{2}{*}{ Model } & \multicolumn{3}{|c|}{$\begin{array}{ll}\text { Unstandardi } & \text { Standardi T } \\
\text { zed } & \text { zed } \\
\text { Coefficients } & \text { Coefficie } \\
& \text { nts }\end{array}$} & \multirow[t]{2}{*}{ Sig. } \\
\hline & B & $\begin{array}{l}\text { Std. } \\
\text { Error }\end{array}$ & Beta & \\
\hline (Constant) & 5,527 & 1,192 & & $4,638 \quad, 000$ \\
\hline $\begin{array}{l}\text { Hasil } \\
\text { perkebunar } \\
\text { kemiri }\end{array}$ & in ,856 &, 044 & ,937 & 19,402,000 \\
\hline
\end{tabular}

\section{Dependent Variabel: kehidupan sosial} ekonomi

Berdasarkan tabel diatas diperoleh nilai konstanta sebesar 5,527 sedangkan untuk variabel hasil perkebunan kemiri 0,856 . Sehingga apabila dimasukan dalam fungsi asli regresi secara keseluruhan maka diperoleh persamaan berikut:

$$
\mathrm{Y}=5,527+0,856 \mathrm{X}
$$

a. Nilai konstanta sebesar 5,527 atau tingkat signifikan 0,000 artinya jika kehidupan sosial ekonomi (X) sebesar 0, maka hasil perkebunan kemiri (y) nilainya adalah 5,527 dan tingkat signifikanya 0,000 .

b. Nilai koefisien hasil perkebunan kemiri( X) sebesar 0,856, maka dapat diartikan bahhwa setiap kenaikan satu satuan hasil perkebunan kemiri (X) akan menaikan 0,856 kehidupan sosial ekonomi (Y).

Berdasarkan hasil uji statistik pearson product moment correlations, diketahui nilai koefisien korelasi antara hasil perkebunan kemiri dengan kehidupan sosial ekonomi sebesar $=0,937$ dengan signifikansi $=0,000 . \quad$ Nilai sig. $=0,000<0,05, \quad$ sehingga hipotesis yang diajukan diterima. Hal ini menunjukan bahwa ada pengaruh antara hasil perkebunan kemiri dengan kehiduan sosial ekonomi masyarakat Desa Benteng Tado Kecamatan Lembor
Selatan Kabupaten Manggarai Barat Nusa Tenggara Timur.

Uji statistik linear sederhana diketahui nilai konstanta sebesar 5,527 sedangkan untuk variabel hasil perkebunan kemiri 0,856 . Sehingga apabila dimasukan dalam fungsi asli regresi secara keseluruhan maka diperoleh persamaan $Y=5,527+0,856 X$. Nilai konstanta sebesar 5,527 atau tingkat signifikan 0,000 artinya jika kehidupan sosial ekonomi (X) sebesar 0, maka hasil perkebunan kemiri (y) nilainya adalah 5,527 dan tingkat signifikanya 0,000. Nilai koefisien hasil perkebunan kemiri( $\mathrm{X})$ sebesar 0,856, maka dapat diartikan bahhwa setiap kenaikan satu satuan hasil perkebunan kemiri (X) akan menaikan 0,856 kehidupan sosial ekonomi (Y).

Berdasarkan hasil beberapa analisis mulai dari analisis korelasi Pearson Product Moment dan analisis regresi linier sederhana, maka hipotesis yang penulis ajukan yakin bahwa hasil perkebunan kemiri memiliki pengaruh yang positif terhadap kehidupan sosial ekonomi masyarakat Desa Benteng Tado Kecamatan Lembor selatan Kabupaten Manggarai Barat Nusa Tenggara Timur. Selain temuan diatas peneliti juga menemukan bahwa masyarakat Desa Benteng Tado yang memiliki perkebunan kemiri juga bekerja sebagai buruh pertanian sawah untuk menambah pendapatan keluarga agar meningkat kondisi ekonominya. Mereka bekerja sebagai buruh pertanian sawah disaat tanaman kemiri sudah dibersihkan dan belum panen. Hal ini dilakukan karena tanaman kemiri merupakan tanaman tahunan karena tanaman kemiri menghasilkan biji kemiri dua kali dalam setahun. 
Pengaruh Hasil Perkebunan Kemiri Terhadap Kehidupan Sosial Ekonomi Mayarakat

Hasil penelitian ini menunjukan adanya pengaruh yang positif antara hasil perkebunan kemiri terhadap kehidupan sosial ekonomi ditunjukan dengan nilai koefisien $0,937, t_{\text {hitung }} 4,638$ dan $t_{\text {tabel }}$ diketahui 2,006. Hal ini menunjukan bahwa $t_{\text {hitung }}>t_{\text {tabel }}$ yaitu 4,638>2,006 dan nilai signifikansi hasil perkebunan kemiri(x) sebesar 0,000 dimana Sig. < $0,05(\alpha=5 \%)$ maka $\mathrm{H}_{0}$ di ditolak yang artinya ada pengaruh antara hasil perkebunan kemiri terhadap kehidupan sosial ekonomi masyarakat Desa Benteng Tado Kecamatan Lembor Selatan Kabupaten Manggarai Barat.

Hal ini sejalan dengan pendapat Sihombing (2011) yang menjelaskan"pengelolaan tanaman kemiri rakyat dari aspek ekonomi cukup memberikan manfaat bagi masyarakat, menyerap tenaga kerja dan layak untuk diusahakan, tetapi pengembangannya terbatas oleh modal yang dimiliki petani'.Pengelolaan tanaman kemiri rakyat dari aspek sosial menunjukkan bahwa distribusi manfaat dari tanaman kemiri cukup memberi dampak yang baik dalam kehidupan masyarakat secara umum.

Hal serupa juga dijelaskan oleh Wibowo (2007) yang menjelaskan"pengusahaan kemiri cukup memberikan kontribusi kehidupan sosial ekonomi bagi petani, pedagang pengumpul dan pengecer dan kegiatan penanaman kemiri menumbuhkan usaha jasa pengupasan kemiri”.

Lebih lanjut Darmawan (2007) menjelaskan "pengusahaan kemiri mempunyai pengaruh secara ekonomi dan bagi kelestarian lingkungan karena pohon kemiri dapat ditanam pada tanahtanah marjinal".

Berdasakan penjelasan peneliti diatas dapat disimpulkan bahwa permintaan buah kemiri akan semakin meningkat seiring dengan semakin meningkatnya jumlah penduduk dan meningkatnya permintaan bahan baku dalam industri. Permintaan bahan baku ini tentu salah satunya kepada mereka yang berusaha di perkebunan kemiri. Sehingga Semakin tinggi permintaan terhadap biji kemiri maka semakin semangat masyarakat mengelola perkebunan kemiri.

\section{KESIMPULAN}

Hasil penelitian ini menunjukan adanya pengaruh yang positif dan signifikan hasil perkebunan kemiri terhadap kehidupan sosial ekonomi masyarakat di Desa Benteng Tado Kecamatan Lembor Selatan Kabupaten Manggarai Barat Nusa Tenggara Timur kehidupan sosial ekonomi ditunjukan dengan nilai koefisien 0,937, thitung 4,638 dan $\mathrm{t}$ tabel diketahui 2,006. Hal ini menunjukan bahwa thitung > ttabel yaitu 4,638 > 2,006 dan nilai signifikansi hasil perkebunan kemiri(x) sebesar 0,000 dimana Sig. $<0,05(\alpha=5 \%)$ maka H0 di ditolak yang artinya ada pengaruh antara hasil perkebunan kemiri terhadap kehidupan sosial ekonomi masyarakat Desa Benteng Tado Kecamatan Lembor Selatan Kabupaten Manggarai Barat Nusa Tenggara Timur.

\section{DAFTAR RUJUKAN}

Astrawan. 2014. Kehidupan Sosial Ekonomi Dalam Kelompok Masyarakat Yang Ditentukan Oleh Aktivitas Ekonomi.

Darmawan. 2007. Pengusahaan Kemiri Mempunyai Pengaruh Secara Ekonomi Dan Bagi Kelestarian Lingkungan. 
Rosman. 2005. Kemiri Tanaman Industri Family Euphorbiaceae Didareh Tropik Dan Suptropik.

Sihombing. 2011. Hasil Perkebunan Kemiri Dipengaruhi Luas Lahan,Umur Tanaman, Jumlah Tanaman.

Sihombing. 2011. Pengelolaan Tanaman Kemiri Rakyat Dari Aspek Ekonomi Cukup Memberikan Manfaat Bagi Masyarakat, Menyerap Tenaga Kerja Dan Layak Untuk Diusahakan.

Wibowo. 2007. Pengusahaan Kemiri Memberikan Kontribusi Kehidupan Sosial Ekonomi Bagi Petani, Pedagang Pengumpul Dan Pengecer. 